\title{
La realidad representada en un film: el caso del cooperativismo
}

Juan Francisco Reinares

Facultad de Humanidades y Ciencias, UNL

\section{Resumen}

En este artículo se pretende rastrear de qué forma se ha representado la realidad histórica vinculada al trabajo cooperativo en comunidades del interior de la provincia de Santa Fe. Es debido a estas razones la elección Palabras clave: trabajo cooperativo, cine documental, modalidades de representación. del film De lo real a lo ideal, ${ }^{1}$ que narra los logros del trabajo cooperativo en la ciudad de Carcarañá, al sur de la provincia.

Contar hoy con producciones audiovisuales de ciudades o pueblos del interior del país es sumamente valioso e importante por la movilización y el trabajo que genera entre sus ciudadanos y por el rescate y preservación de su memoria. Vale preguntarnos por las posibilidades, los alcances y las limitaciones que tiene el material audiovisual.

1. Documental de Patricio Herrmann y Alejandro Molnar. 


\section{Abstract}

This article intended to seek ad trace how it has been represented the historical reality linked to cooperative work in communities in the interior of the province of Santa Fe is due to this reason the choice of film: From

\section{Keywords:}

cooperative work, documentary film, modes of representation. the real to the ideal, that chronicles the achievements of cooperative work in the city of Carcarañá, south of the province.

Counting today, with audiovisual productions of cities or villages in the interior, is extremely valuable and important for the mobilization and work generates among its citizens and for the recovery and preservation of his memory. Well wonder about the possibilities, the scope and limitations of the audiovisual material.

\section{Introducción: ¿en qué sentido el material audiovisual constituye una fuente para la historia?}

Resulta significativo recuperar tendencias y categorías analíticas para discutir esta pregunta. El análisis realizado recupera los principales aportes teóricos de los estudios culturales, los que surgieron en los márgenes de discursos de otros estudios como los literarios, la sociología, la historia, y en menor medida la lingüística, la semiótica, la antropología y el psicoanálisis. El término refiere a diferentes metodologías interdisciplinarias de investigación. Esta perspectiva se conforma como una corriente con la creación del Centro de Estudios Culturales Contemporáneos en 1964 en la Universidad de Birmingham. Desde su institucionalización, los estudios culturales plantean la crítica hacia corrientes tradicionales, niegan esta tradición para entender los procesos culturales como una realidad emergente del contexto histórico. A partir de ellos, el concepto de cultura se modifica: «donde cultura significaba un estado o hábito de la mente, o el conjunto de actividades intelectuales y morales, significa ahora también, toda una forma de vida» (Acuña, 1999:7).

A partir de las décadas de 1960 y 1970 «empezó a percibirse una situación de pérdida de seguridad en las doctrinas y los diagnósticos que habían guiado el desarrollo de la investigación social en los treinta años anteriores» (Aróstegui, 1995:134). Paralelamente se produjo una variación de cambios disciplinares centrados en 